ББК 63.4

$$
\begin{gathered}
\text { Организация конференции и издание материалов проведены } \\
\text { при финансовой поддержке Российского фонда фундаментальных исследований, } \\
\text { проект № 19-09-20008 }
\end{gathered}
$$

Утверждено к печати Ученым советом ИИМК РАН

Редакционная коллегия тома II: А. В. Поляков, Е. С. Ткач (отв. редакторы), М. Т. Кашуба, Л. Б. Кирчо, Е. А. Черлёнок, В. Я. Стёганцева, А. И. Климушина

Рещензенты: д. и. н. Л. Б. Вишняцкий, д. и. н. А. А. Выборнов

Программный комитет конференции: академик РАН, д. и. н., проф. М. Б. Пиотровский (Государственный Эрмитаж, почетный председатель); д. и. н. В. А. Лапшин (ИИМК РАН, председатель); д. и. н. А. В. Головнёв (МАЭ РАН, сопредседатель); д. и. н. В. А. Дергачёв (Высшая антропологическая школа, Молдова, сопредседатель); д. и. н. И. Ф. Попова (ИВР РАН, сопредседатель); академик АН Республики Узбекистан, д. и. н., проф. Э. В. Ртвеладзе (сопредседатель); к. и. н. А. В. Поляков (ИИМК РАН, зам. председателя); к. и. н. В. А. Алёкшин (ИИМК РАН, зам. председателя); д. и. н. Ю. Е. Берёзкин (МАЭ РАН); Dr., Prof. Н. Бороффка

(Германский археологический институт, Германия); В. С. Бочкарёв (ИИМК РАН);

Dr. Э. Кайзер (Свободный университет Берлина, Германия); к. и. н. М. Т. Кашуба (ИИМК РАН); д. и. н. Л. Б. Кирчо (ИИМК РАН); к. и. н. А. В. Кияшко (Южный федеральный университет); к. и. н. П. Ф. Кузнецов (СГСПУ); к. и. н. Н. М. Малов (СНИГУ); к. и. н. В. П. Никоноров (ИИМК РАН); Ю. Ю. Пиотровский (Государственный Эрмитаж); д. и. н., проф. Д. Г. Савинов (Институт истории СПбГУ); к. и. н. В. Н. Седых (Институт истории СПбГУ); к. и. н. Н. Н. Скакун (ИИМК РАН); к. и. н. Н. Ф. Соловьёва (ИИМК РАН); к. и. н. А. И. Торгоев (Государственный Эрмитаж); к. и. н. Е. А. Черлёнок (Институт истории СПбГУ)

Организационный комитет конференции: к. и. н. А. В. Поляков (ИИМК РАН, председатель); к. и. н. В. А. Алёкшин (ИИМК РАН, зам. председателя); В. С. Бочкарёв (ИИМК РАН); к. и. н. М. Т. Кашуба (ИИМК РАН); д. и. н. Л. Б. Кирчо (ИИМК РАН);

А. И. Климушина (ИИМК РАН, отв. секретарь); к. и. н. В. П. Никоноров (ИИМК РАН); Ю. Ю. Пиотровский (Государственный Эрмитаж); В. Я. Стеганцева (ИИМК РАН); В. В. Терёхина (ИИМК РАН, МАЭ РАН, отв. секретарь); к. и. н. Е. С. Ткач (ИИМК РАН); И. Ж. Тутаева (Государственный Эрмитаж); к. и. н. Е. А. Черлёнок (Институт истории СПбГУ)

Древности Восточной Европы, Центральной Азии и Южной Сибири в контексте связей и взаимодействий в евразийском культурном пространстве (новые данные и концепции): Материалы Международной конференции, 18-22 ноября 2019 г., Санкт-Петербург. Т. ІІ. Связи, контакты и взаимодействия древних культур Северной Евразии и цивилизаций Востока в эпоху палеометалла (IV-I тыс. до н. э.). К 80-летию со дня рождения выдающегося археолога В. С. Бочкарёва. - СПб.: ИИМК РАН, Невская Типография, 2019. - 287 с.

ISBN 978-5-907053-35-9

DOI 10.31600/978-5-907053-35-9 


\title{
Литература
}

Братченко С. Н. 1976. Нижнее Подонье в эпоху средней бронзы. Киев.

Власкин Н. М. 2010. Сравнительная характеристика катакомбных культур манычского типа эпохи средней бронзы: автореф. дис. ... канд. ист. наук. СПб.

Городцов В. А. 1907. Результаты археологических исследований в Бахмутском уезде, Екатеринославской губернии в 1903 г. // Тр. XIII Археологического съезда в Екатеринославле в 1905 г. М. Т. 1. С. 210-285.

Смирнов А. М. 1996. Курганы и катакомбы эпохи бронзы на Северском Донце. М.

\section{BURIALS WITH CERAMICS OF MANYCH CULTURES ON THE RIGHT BANK OF THE LOWER DON}

\author{
Anastasiya Yu. Chechina \\ Institute of History and International Relations of the Southern Federal University, Rostov-on-Don, \\ Russia
}

Keywords: Lower Don, Seversky Donets river, Middle Bronze Age, kurgans, burials, Donets catacomb culture, Manych culture, Bakhmut culture, Rostov-Lugansk group.

This study attempts to explore the cultural processes that took place on the Lower Don during the late phase of the Catacomb cultures. At the developed stage, various cultures of the nearby territories began to affect the Donets Catacomb culture. The local migrations were expanding. On this basis, new cultures and cultural groups began to arise. The influence of the left-bank Catacomb cultures expanded and the Manych groups actively penetrated the territory of the right bank of the Don River. This fact suggests a significant strengthening of the Manych catacomb cultures with a simultaneous weakening of the Donets Catacomb culture.

\section{КУЛЬТУРНО-ГЕНЕТИЧЕСКИЕ ПРОЦЕССЫ НА ВОСТОКЕ ПОСТКАТАКОМБНОГО МИРА}

\author{
Р. А. Мимоход \\ Институт археологии РАН, Москва, Россия
}

DOI: 10.31600/978-5-907053-35-9-39-41

Ключевые слова: посткатакомбные культуры, культурный круг Бабино, культурный круг Лола, хронология, колесничные культурь.

В финале среднего бронзового века на генетической основе катакомбных культур возник блок посткатакомбных культурных образований. Он состоял из культурного круга Бабино и культурного круга Лола. В первый входил днепро-прутская, днепро-донская и волго-донская бабинские культуры, во второй - лолинская культура, волго-уральская, кубанская и архонская культурные группы. Различия культурных кругов обусловлены разными механизмами происхождения лолинских и бабинских древностей. Одним из важных компонентов сложения культурного круга Бабино оказался импульс из Центральной Европы и Карпато-Балканского региона, который хорошо фиксируется в некоторых чертах погребального обряда и инвентаря. В полном виде этот импульс реализовался в сложении средневолжской абашевской культуры, которая обладает целым комплексом среднеевропейских и карпато-дунайских черт. Миграция европейского населения на Волгу, проходившая, по всей видимости, в пограничье лесостепи и леса, затронула катакомбный мир, в особенности Среднего Подонья. Это стимулировало возникновение культурного круга Бабино и широкое распространение многоваликовой орнаментации керамики. В свою очередь ге- 
незис культурного круга Лола был связан с миграцией восточнокавказского населения в степь. Эти два вектора, европейский и кавказский, обусловили структуру и содержание блока посткатакомбных культурных образований. Особенно важно отметить, что указанные миграционные процессы конца XXIII-XXII вв. до н. э. были вызваны сильной аридизацией, которая хорошо фиксируется как по палеоклиматическим данным в Европе, так и по историческим источникам Ближнего Востока.

Под восточной частью посткатакомбного мира подразумевается территория Нижнего Поволжья, Волго-Уралья и Предкавказья. В первом регионе основной культурный контекст представлен волго-донской бабинской культурой, в двух других - памятниками культурного круга Лола (лолинской культурой, кубанской, волго-уральской и архонской культурными группами). Таким образом, очерченный ареал интересен тем, что здесь взаимодействовали носители лолинских и бабинских традиций. Случаи обратной стратиграфии между погребениями волго-донской бабинской и лолинской культур свидетельствуют об их синхронности. Это подтверждают и радиоуглеродные данные. На сегодняшний день для блока посткатакомбных культурных образований мы имеем 81 дату. Время его существования определяется как 2200-1800 cal BC. Историческая судьба культурных образований финала средней бронзы в восточной части посткатакомбного мира была тесно связана с возникновением и экспансией колесничных культур. Волго-донская бабинская культура и волго-уральская культурная группа, которые находились в эпицентре волго-уральского очага культурогенеза, были поглощены новыми военизированными культурами начальной фазы позднего бронзового века и стали одним из компонентов их формирования. В результате хронология волго-донской бабинской культуры и волго-уральской культурной группы оказалась короче, чем время существования лолинской и днепро-донской бабинской культур. Посткатакомбные культурные образования Нижнего Поволжья и Волго-Уралья прошли в своем развитии только два этапа, в то время как остальные составляющие блока - три периода. Лолинские группы были вытеснены носителями покровской традиции из Нижнего Поволжья в Предкавказье, в пределы своего основного ареала, где и существовала культура с момента возникновения и до своей завершающей (третьей) фазы. Экспансия «покровцев» в западном направлении привела к смещению ареала днепро-донской бабинской культуры за Дон и Северский Донец. До этого, на раннем и развитом этапе, она достигала волго-донского междуречья, вплоть до правобережных притоков Волги. Третий (заключительный) период развития культурного круга Бабино ограничивался только территорией степной и лесостепной зон современной Украины.

\title{
CULTURAL GENETIC PROCESSES IN THE EAST OF THE POST-CATACOMB WORLD
}

\author{
Roman A. Mimokhod \\ Institute of Archaeology RAS, Moscow, Russia
}

Keywords: post-Catacomb cultures, Babino cultural circle, Lola cultural circle, chronology, chariot cultures.

On the genetic basis of the Catacomb cultures in the final Middle Bronze Age, there arose a block of Post-Catacomb cultural formations. It included the cultural circle of Babino and the cultural circle of Lola. The first included the Dnieper-Prut, Dnieper-Don and Volga-Don Babino cultures; the second group comprised the Lola culture, Volga-Ural, Kuban and Arkhon cultural groups. The time of the existence of the block is within the $22^{\text {nd }}-18^{\text {th }}$ cent. cal BC. Under the eastern part of the Post-Catacomb world, the regions of the Lower Volga, Volga-Ural and Ciscaucasia are here implied. In the first region, the main cultural context is represented by the Volga-Don Babino culture, in the other two these are 
sites of the cultural circle of Lola. The historical destiny of the post-Catacomb cultural formations was closely connected with the appearance and expansion of the chariot cultures. The Volga-Don Babino culture and the Volga-Ural cultural groups, having found themselves in the epicenter of the Volga-Ural cradle of cultural genesis, were consumed by the new militarized cultures of the initial phase of the Late Bronze Age and became one of the components of the latter's formation.

\title{
ДАТИРОВКА ТАК НАЗЫВАЕМОГО СТЕПНОГО СОСУДА ИЗ ПОСЕЛЕНИЯ ТАИП-ДЕПЕ 1 В ДРЕВНЕЙ ДЕЛЬТЕ МУРГАБА (ЮЖНЫЙ ТУРКМЕНИСТАН)
}

\author{
В. А. Алёкшин \\ Институт истории материальной культуры РАН, Санкт-Петербург, Россия
}

DOI: 10.31600/978-5-907053-35-9-41-44

Ключевые слова: Центральная Азия, Северо-Восточный Иран, поздний бронзовый век, Tаип-депе 1, дельта Мургаба, Тепе Гиссар, орнамент, глиняный сосуд.

При раскопках древнеземледельческих поселений Южного Туркменистана в культурных отложениях, относящихся к позднему бронзовому веку, иногда находят лепную посуду, представленную в основном фрагментами. Способ ее изготовления не имеет ничего общего с технологией местного гончарного производства. Речь идет о черепках сосудов, характерных для быта пастушеских племен степей Евразии. Культурно-хронологическая атрибуция большинства найденных обломков этой посуды не установлена, так как упомянутые артефакты, как правило, представлены мелкими бедно орнаментированными фрагментами, которым трудно найти полные соответствия в керамике той или иной археологической культуры, распространенной к северу от земледельческих оазисов Туркменистана.

Для определения времени контактов оседлых и пастушеских племен важны находки целых степных сосудов на земледельческих поселениях. Один из них обнаружен на памятнике Таип-депе 1 (рис. 1, 1) в древней дельте Мургаба без указания археологического контекста и стратиграфической позиции этого артефакта. Горшок не имеет налепного валика, и, следовательно, не может быть датирован позднее, чем эпоха развитой фёдоровской культуры. Орнаментальная композиция, представленная на сосуде, выполнена в архаичной манере, когда узор покрывает всю поверхность изделия. Эта традиция, восходящая к эпохе неолита, не прослеживается, однако, в кельтеминарской культуре Центральной Азии. Не характерна она и для культуры степной бронзы Заман-баба, распространенной в низовьях Зеравшана. Для северных территорий, лежащих вне Центральной Азии (Поволжье, Зауралье), данный стиль фиксируется в неолите - энеолите (рис. 1, 3-6), а в Казахстане начиная с энеолита, причем расположение орнамента на горшке из Таип-депе 1 обнаруживает большое сходство с манерой украшения посуды полтавкинской культуры среднего бронзового века в Среднем Поволжье (рис. 1, 7-9). Сохраняется эта традиция и в начале позднего бронзового века, где она выявлена для потаповской в Среднем Поволжье (рис. 1, 10-12) и синташтинской в Зауралье (рис. 1, 13-15) культур. Позднее, в ранних срубных (рис. 1,16$)$ и ранних алакульских (рис. 1,17$)$ памятниках данная манера украшения сосудов встречается крайне редко (Среднее Поволжье, Центральный Казахстан). Теперь узоры покрывают в основном не более двух верхних третей поверхности гончарных изделий (рис. 1,18$)$. Степной горшок из Таип-депе 1 обнаружен в одном контексте с такой формой сосуда как кубок на ножке (рис. 1, 2). Последний характерен для керамических комплексов первого этапа культуры позднего бронзового века (рис. 1, 19-21), распространенной на юге 